\title{
Farmers' perception on quality of fish feed, brood stock and fingerling produced in commercial fish farms of Bangladesh
}

\author{
MD. SAZEDUR RAHMAN, HASSAN MAHMUD RIAD, MD. SAYEM MAHMUD \\ MST. KANIZ FATEMA AND MD. SHAHJAHAN* \\ Department of Fisheries Management, \\ Bangladesh Agricultural University, Mymensingh 2202, Bangladesh \\ *Email: mdshahjahan@bau.edu.bd
}

\begin{abstract}
In Bangladesh, aquaculture has expanded, diversified, intensified and technologically advanced due to the decline in fish production from the open water natural sources. Quality seeds are prime requirements for aquaculture production. Quality of seeds depends on the quality of broods used for spawning. Breeding performance depends on the quality of feeds and feeding management during brood stock rearing. The present study focused on the evaluation of quality of feed used in the fish farms, the performance of brood stock and fingerlings of selected carp, catfish and perch farmed in Bangladesh through a survey. On the basis of top fish production districts, we divided the whole country into four hubs, such as Mymensingh, Jashore, Cumilla and Rajshahi. Data were collected from 300 individual respondents of commercial fish farms, 75 from each hub. It has been found that most of the farm owners $(91 \%)$ used commercial feed instead of homemade feed, though a considerable number of respondents replied that quality of homemade feed was better than commercial feed. Although most of the farm owners collect fry from private/own hatcheries (69\%), a considerable number of grow out farms owners replied that the fry of government hatcheries/brood bank, river and BFRI were better than private hatcheries in terms of growth performance, disease resistance and survivability. Therefore, for sustainable aquaculture, farm owners should be careful for the selection of feed, brood and fingerling.

Keywords: Feed, Brood fish, Seed, Aquaculture, Fish farm
\end{abstract}

\section{Introduction}

Bangladesh is a land of rivers and is blessed with an rich biodiversity of fish and fisheries resources. Fisheries play a vital role in nutrition, employment, income generation and foreign exchange earnings. Fisheries sector provides about $60 \%$ of the animal protein intake and more than $11 \%$ of the total population of the country is directly or indirectly involved in this sector for their livelihoods (DoF 2013). However, due to the degradation of ecological balance, fish production from open water natural resources has been declined. Thus aquaculture has expanded, diversified, intensified and technologically advanced in Bangladesh. With the increased intensification and commercialization of aquaculture practice, quality of fish seeds and fish health somewhat decreased and became one of the most important issues to aquaculturists (Amin et al. 2005, Bondad-Reantaso et al. 2005, Al-Hasan et al. 2014, Hossain et al. 2020).

Historically fish farming has been a part time activity of the peasant farmers who developed it as an efficient mean of utilizing farm resources to the maximum extent. Indian major carps, some exotic carps and catfishes are the main cultured species for the closed water system and production of these species completely depends on timely and adequate supply of quality seed. 
Until very recent times, carp culture in pond remained the main stay of aquaculture globally including Bangladesh. However, a number of other fish have been added to the species combinations with the expectation of increasing productivity in polyculture pond (Uddin et al. 2007, Uddin et al. 2012, Samad et al. 2013). Brood fish is considered as the heart of the hatchery and management of broodstock is the key of quality seed production. Success of induced breeding depends on availability of sufficient number of brood fish. Therefore, brood stock should be managed scientifically so that mature broods could be obtained during the whole breeding season. Most of the government hatcheries have their own brood stock and around 25 percent recruitments take place in every year. On the other hand, few private hatcheries have their own brood stock and maintain them more or less scientifically but there are many private hatcheries that do not have the required number of broods. During the breeding season, they instantly buy broods from others and produce fry from them to fulfill their target (Sarder et al. 2002). Feed quality is another important issue to maintain a good brood stock to get quality seeds.

Quality seeds are prime requirements for aquaculture productions and business. Quality of seeds depends on the quality of broods used for spawning. Breeding performance depends on the quality of feeds and feeding management during brood stock rearing. Therefore, it is necessary to know the quality of fish feed, brood used and fingerlings produced in commercial fish farms of Bangladesh. The present study focused on the evaluation of quality of feed used in the fish farms, the performance of brood stock and fingerlings of selected carp, catfish and perch farmed in Bangladesh through survey.

\section{Materials and Methods}

On the basis of top fish production districts, we divided the whole country into four hubs, such as Mymensingh, Jashore, Cumilla and Rajshahi (Fig. 1). Data were collected from 300 individual respondents of commercial fish farms located in the four hubs, 75 from each. Literature review, semi structured questionnaire interview, structured and in-depth interview, and focus group discussions were employed to assess the current status of commercial fish farms in Bangladesh.

\section{Results and Discussion}

Data were collected from 300 individual respondents of commercial fish farms located in Mymensingh, Rajshahi, Jashore and Cumilla regions to know the farm owners perception on the quality of feed, brood and fingerlings.

Scenario of use of feed by the farms: It has been found that most of the farms use commercial feed instead of homemade feed (Fig. 2). During the study period, users of commercial and homemade feed were recorded as $91 \%$ and $9 \%$, respectively in all over the country. Similar trends were recorded in case of Mymensingh, Rajshahi and Jashore regions. Interestingly, in Cumilla region, a remarkable number of farm owners (89\%) use both the commercial and homemade feeds. Use of manufactured feeds in aquaculture in Bangladesh has grown rapidly over the last five years. More than one million tons of commercially formulated feeds and 0.30.4 million tons of farm-made feeds were produced in 2012 (Mamum-Ur-Rashin et al. 2013). 


\section{FARMERS’ PERCEPTION IN COMMERCIAL FISH FARMS OF BANGLADESH}

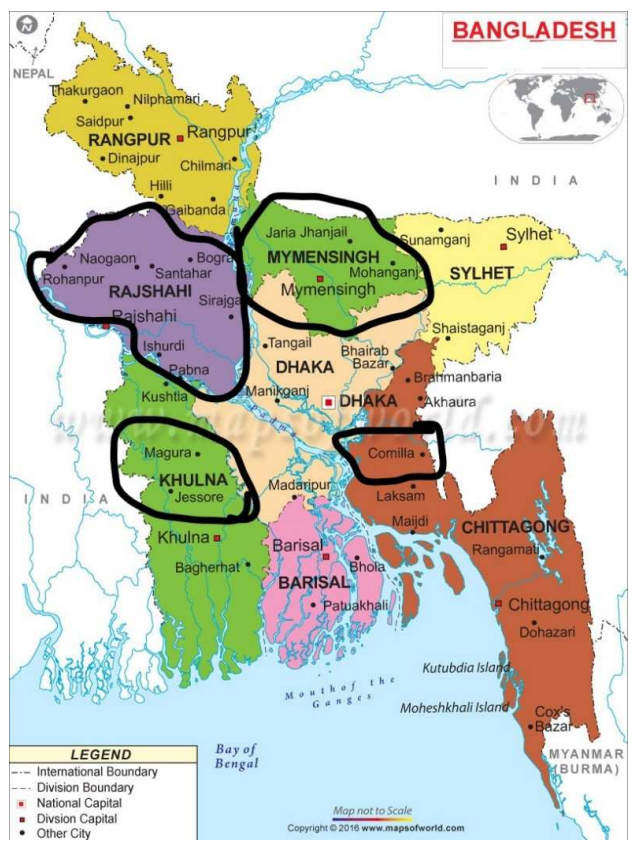

Fig. 1. Map of Bangladesh for showing the four hubs: Mymensingh, Rajshahi, Cumilla and Jashore.

a
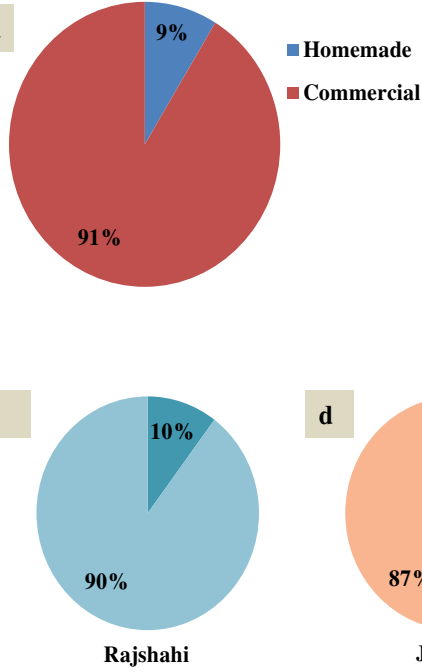

d

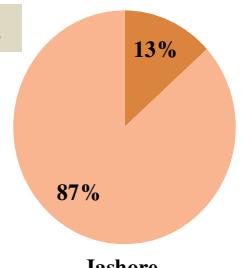

b

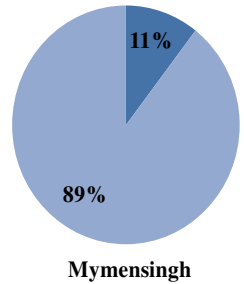

e

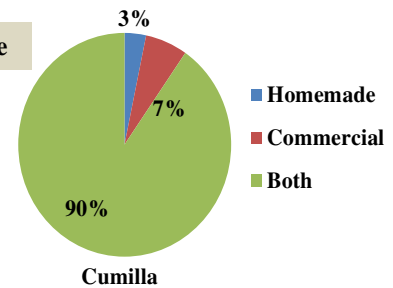

Fig. 2. Scenario of feed uses by farm owners; a) overall country, b) Mymensingh, c) Rajshahi, d) Jashore, and e) Cumilla region. 
Farmers' perception on quality of feed: During the study period, we asked the farm owners about the quality of fish feed on the basis of cost, reliability, availability, growth performance, organic and labor intensiveness. A considerable proportion of the respondents replied that quality of homemade feed was better than the commercial feed (Fig. 3a). However, most of the farm owners use commercial feed instead of homemade feed as because of easily available and less labor intensive (Fig. 3b).

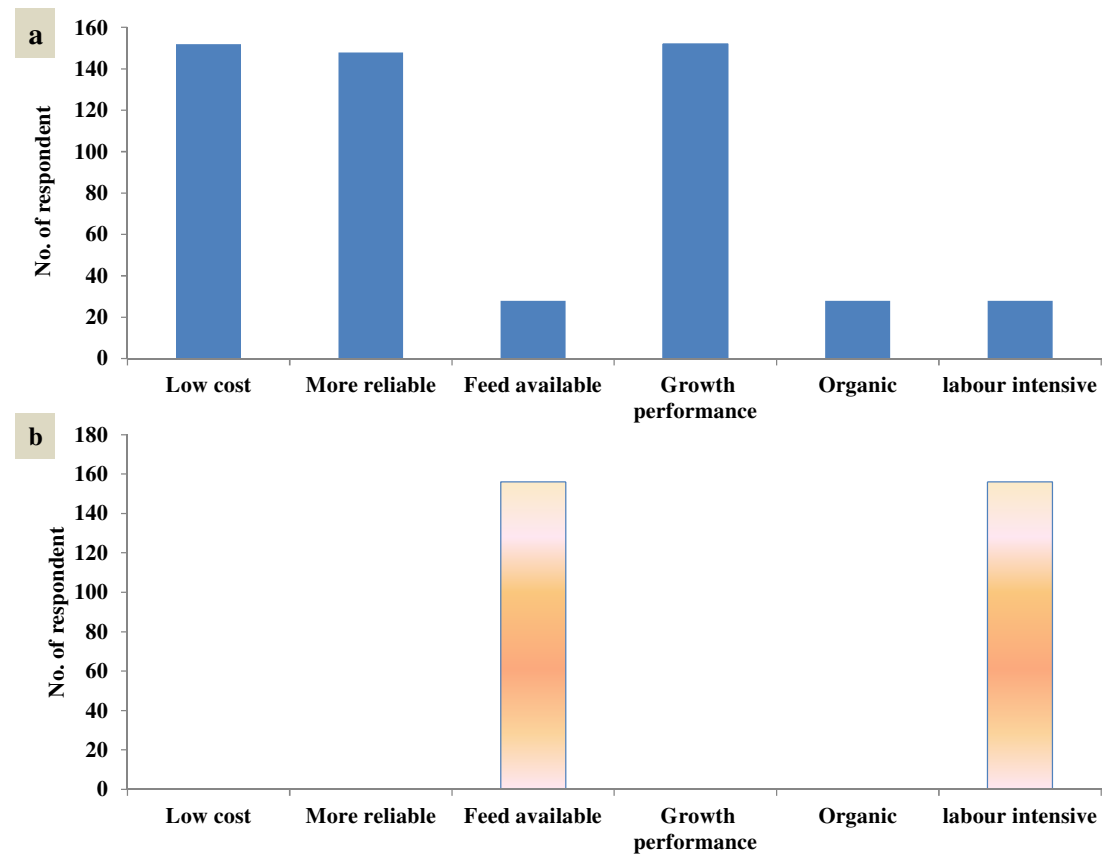

Fig. 3 Farmers' perception on quality of feed; a) homemade feed, b) commercial feed.

Farmers' perception on quality of brood: During the study period, we asked the farms owners about the sources and quality of brood fish used for induced breeding in different hatcheries of Bangladesh. Highest number of respondent used brood fish from their own hatcheries followed by the river, BFRI, government brood bank and other hatcheries (Fig. 4). Interestingly, most of the farm owners replied that the qualities of brood of their own hatcheries were better (Fig. 5). Hossain et al. (2016) reported that the main source of brood of Indian major carps included the WorldFish Center (15\%), BFRI (8\%), Halda river (19\%), Padma river (12\%), government brood bank (15\%), own hatchery $(23 \%)$ and others sources $(8 \%)$. The main purpose of collecting brood from different sources is to avoid (or reduce) inbreeding and produce quality seed. Preferably 1 to 3 years of age weighing from $3.5 \mathrm{~kg}$ to $8 \mathrm{~kg}$ mature males and females should be collected from the natural sources (rivers, lakes, and reservoirs) as brood stock (Sarder et al. 2002). 


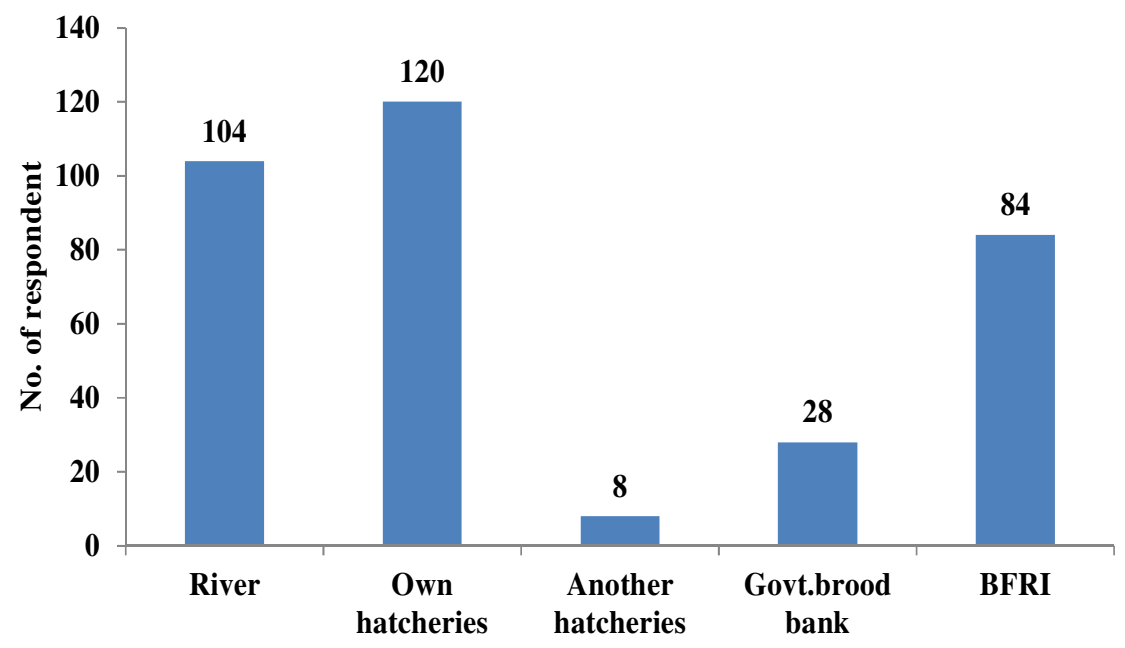

Fig. 4. Sources of brood fish used for induced breeding in different hatcheries of Bangladesh

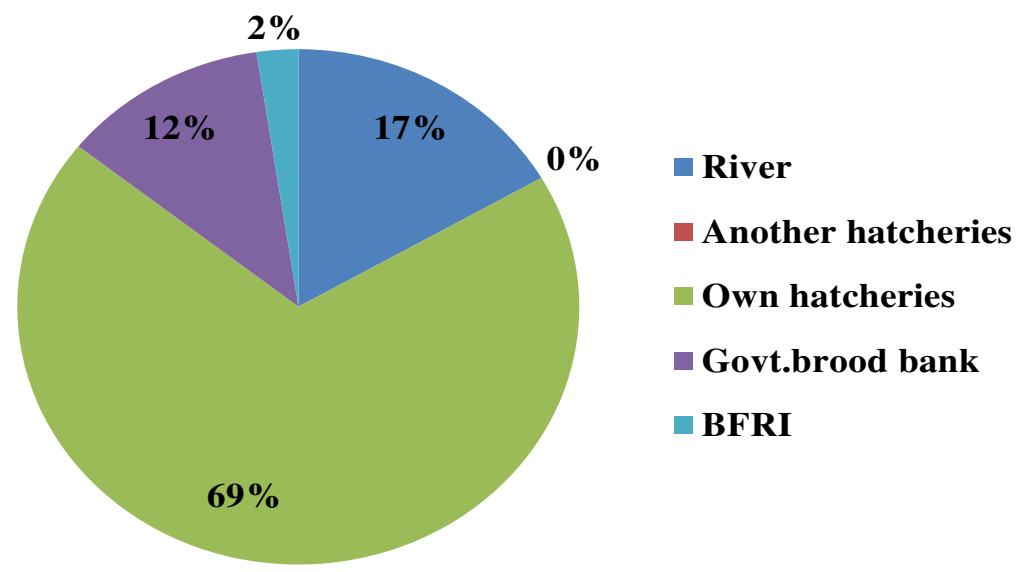

Fig. 5 Responses of farms owners about the quality of brood fish used for induced breeding in different hatcheries of Bangladesh.

Farmers' perception on quality of fry: During the study period, we asked the farm owners about the sources and quality of fry collected for grow out pond. Highest number of respondent collected fry from private hatcheries followed by the government hatcheries, river, brood bank and BFRI (Fig. 6). Asif et al. (2014) reported that marketing channel of fish fry and fingerling started with brood pond and continued through the hatchery, nursery, fry and fingerling traders, intermediates, buyer, farmer, then farming pond or rearing pond. Sharif and Abdulla-Al-Asif (2015) showed that the channel started with Brood Fish (collection mainly from Halda and Jamuna River) then hatchling Production, nursery owners, fry production, wholesaler, Retailer 
and finally end with the fish Farmer. Although most of the farm owners collect fry from private hatcheries, a considerable number of grow out farm owners replied that the fry of government hatcheries, river, brood bank and BFRI were better than the private hatcheries in terms of growth performance, disease resistance and survivability (Fig. 7).

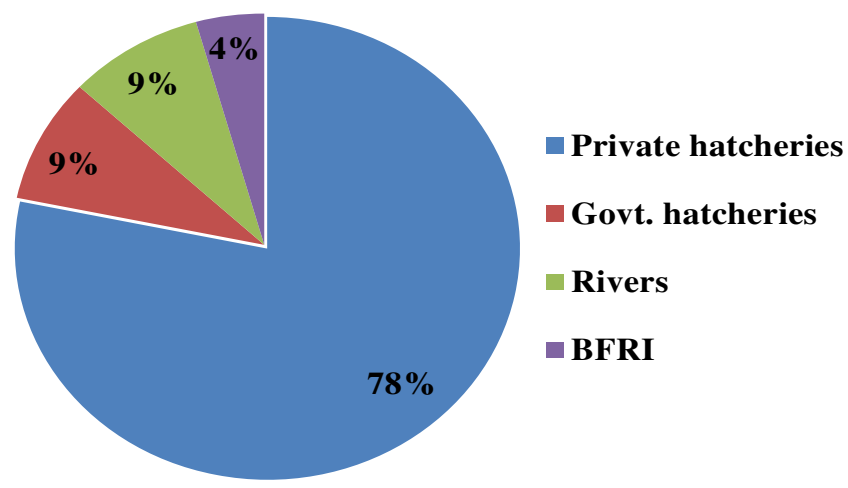

Fig. 6 Sources of fries collected for grow out pond culture in Bangladesh.

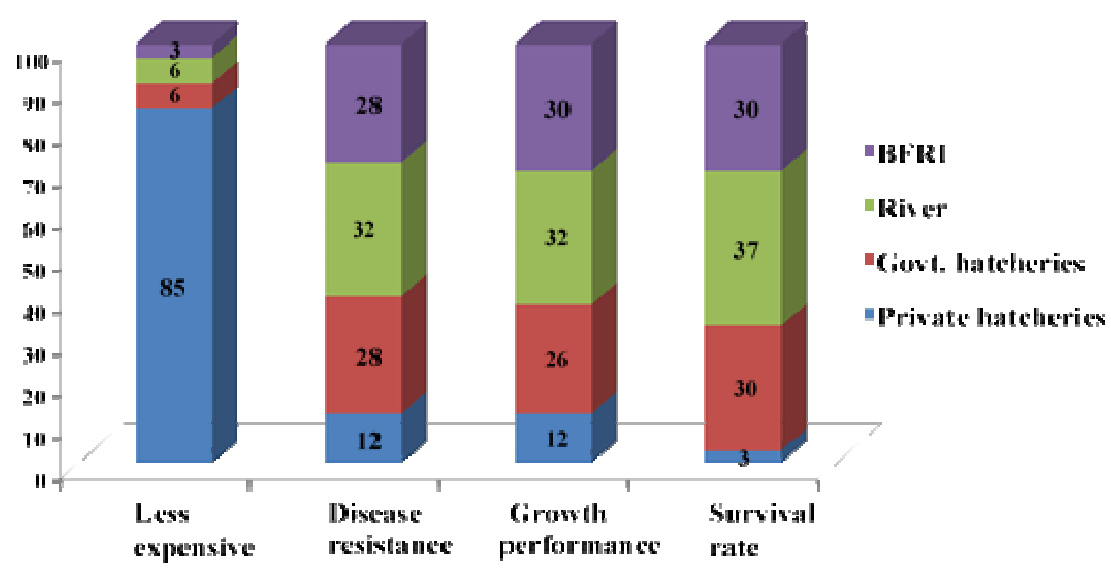

Fig. 7. Responses of farms owners about the quality of fries collected for grow out pond culture in Bangladesh.

Conclusion: In the present study, we evaluated the quality of feed used in the fish farms, the performance of brood stock and fingerlings of selected carp, catfish and perch farmed in Bangladesh based on the farmers' perceptions. The data showed that large differences exist within and between various commercial fish feeds. Emphasis should be given on expansion of hatchery facilities to supply high quality fish seeds required to support aquaculture development. More future works are necessary on different aspects of fish feed and seed production. The 
FARMERS' PERCEPTION IN COMMERCIAL FISH FARMS OF BANGLADESH

government and NGOs should provide all modern facilities in connection with the quality fish seeds production ensuring quality feeds in Bangladesh.

Acknowledgment: This work was made possible by grants from the National Agricultural Technology Program-Phase II Project (CRG-364), Bangladesh Agricultural Research Council, Dhaka, Bangladesh.

\section{Literature Cited}

Al-Hasan, A., M. Shahjahan, M.M. Hossain and M.M. Haque, 2014. Fish availability and marketing system at three markets in Barisal, Bangladesh. Int. J. Innov. Appl. Stud., 7 (2): 765-773.

Amin, A.K.M.R., M.A.J. Bapary, M.S. Islam, M. Shahjahan and M.A.R. Hossain, 2005. The impacts of compensatory growth on food intake, growth rate and efficiency of feed utilization in Thai pangas. Pakistan J. Biol. Sci., 8: 766-770.

Asif, A.A., M.A. Samad, B.M.S. Rahman, M.A. Rahman, M.H. Rahman, S.M. Yeasmin and A. Nima. 2014. Study on management of fish fry and fingerling marketing of Jessore in Bangladesh. Int. J. Busin. Soci. Sci. Res., 2(2): 127-135.

Bondad-Reantaso, M.G., R.P. Subasinghe, J.R. Arthur, K. Ogawa, S. Chinabut, R. Adlard, 2005. Disease and health management in Asian aquaculture. Veterinary Parasitol, 132: 249-272.

DoF, 2013. Fisheries Statistical Yearbook of Bangladesh 2011-2012. Fisheries Resources Survey System (FRSS), Department of Fisheries, Bangladesh..

Hossain, M.M., M.H. Rahman, M.L. Ali, S. Khan, M.M. Haque and M. Shahjahan, 2020. Development of a low-cost polyculture system utilizing Hygroryza aristata floating grass in the coastal wetlands of Bangladesh. Aquaculture, 527: 735430.

Hossain, M.T., M.S. Alam, M.H. Rahman, Abdulla-Al-Asif and S.M. Rahmatullah, 2016. Present status of Indian major carp brood stock management at the hatcheries in Jessore region of Bangladesh. Asian Australasian J. Biosci. Biotechnol., 1 (2): 362-370.

Mamun-Ur-Rashid, M., B. Belton, M. Phillips and K.A. Rosentrater, 2013. Improving aquaculture feed in Bangladesh: From feed ingredients to farmer proft to safe consumption. WorldFish, Penang, Malaysia. Working Paper: 2013-34.

Samad, M.A., M.T. Hossain and B.M.S. Rahman, 2013. Present status of brood stock management at carp hatcheries in Jessore. J. Bangladesh Agril. Univ., 11(2): 349-358,

Sarder, A.S., M.R. Azam and M.A. Hossain, 2002. Private hatchery owners' perspectives on hatchery management in Bangladesh. In: D.J. Penman, M.G. Hussain, B.J. McAndrew and M.A. Mazid. (eds.). Proc. of a workshop on Genetic Management and Improvement Strategies for Exotic Carps in Asia, 12-14 February 2002, Dhaka, Bangladesh. Bangladesh Fisheries Research Institute, Mymensingh, Bangladesh. 78 p.

Sharif, B.M.N. and Abdulla-Al-Asif, 2015. Present status of fish hatchlings and fry production management in greater Jessore, Bangladesh. Int. J. Fish. Aquat. Stud., 2(5): 123-127.

Uddin, M.N., M.S. Rahman and M. Shahjahan, 2007. Effects of duckweed (Lemna minor) as supplementary feed on monoculture of GIFT strain of tilapia (Oreochromis niloticus). Progress. Agricult., 18 (2): 183-188.

Uddin, M.N., M. Shahjahan and M.M. Haque, 2012. Manipulation of species composition in small scale carp polyculture to enhance fish production. Bangladesh J. Progress. Sci. Technol., 10(1): 9-12. 